Secuencia (2003), 57, septiembre-diciembre, 61-90

ISSN: 0186-0348, ISSN electrónico: 2395-8464

DOI: http://dx.doi.org/10.18234/secuencia.v0i57.825

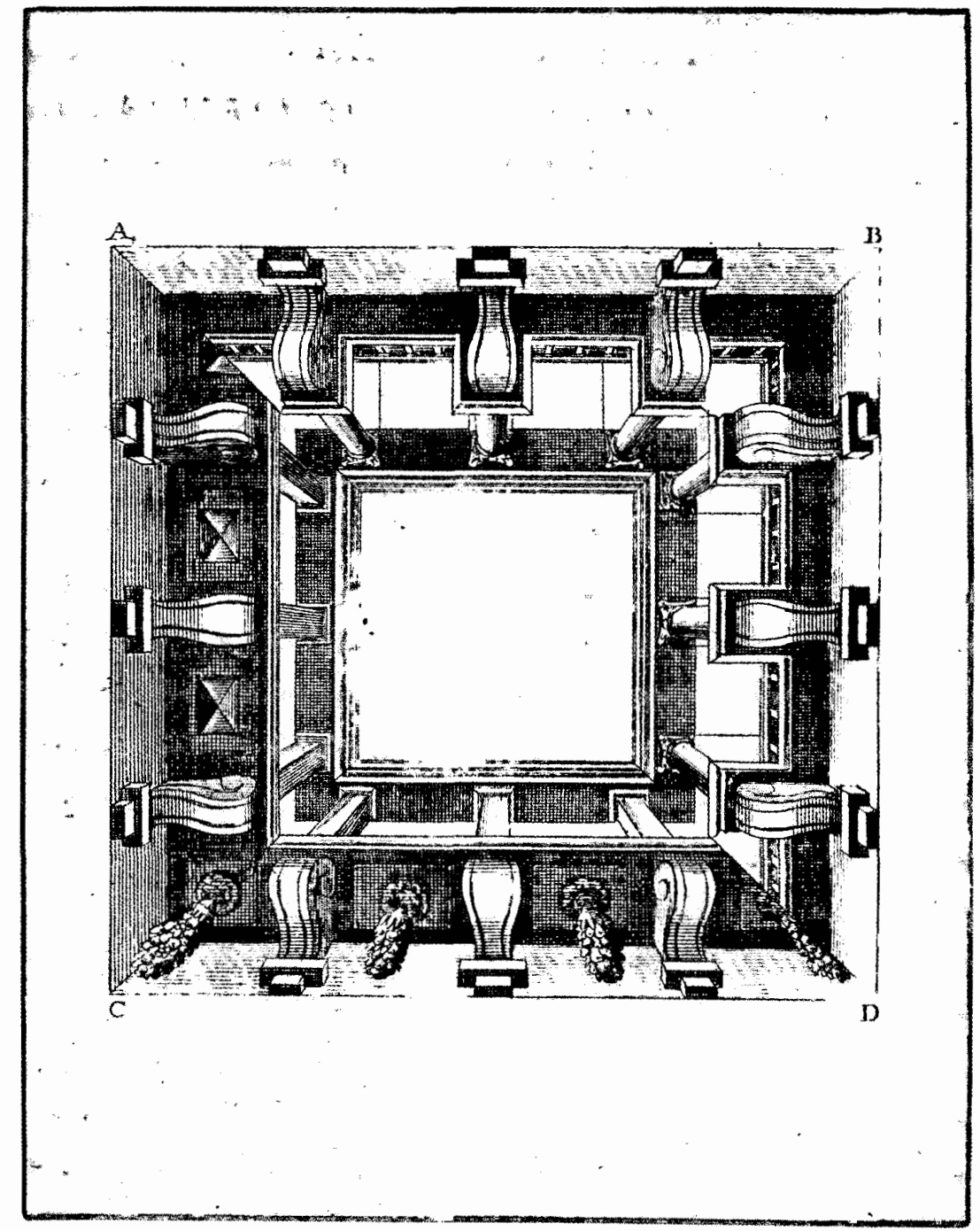




\section{José Lee Borges}

Maestro en Historia de Puerto Rico y el Caribe. Actualmente cursa estudios doctorales en el Programa Graduado de Historia de la Universidad de Puerto Rico. Es profesor de Historia en la Universidad de Puerro RicoRecinto Río Piedras. Articulista de varios periódicos de República Dominicana y Puerto Rico, como Tiempos del Mundo y El Nuevo Día. Entre sus publicaciones destacan, "U. S. Consular Activism in the Caribbean (1783-1903), with Especial Reference to St. Kitts-Nevis, Sugar Depression, Labor Turmoil and its Proposed Acquisition by the United States", Revista Mexicana del Caribe, núm. 5, 1998, y "República Dominicana, de la restauración a los primeros pasos de la 'verdadera' influencia estadunidense, 1865-1880", Revista Mexicana del Caribe, núm. 10, 2000.

\section{Resumen}

Este trabajo estudia la competencia y rivalidad que se desataron entre las grandes potencias europeas -especialmente España- y Estados Unidos, para lograr mayor poder económico y político en República Dominicana, en el periodo de 1844 a 1865. Pone de relieve el papel desempeñado por los primeros "agentes comerciales" o "cónsules" estadunidenses en el país, quienes se enfrentaron con los distintos diplomáticos europeos. Utilizando la correspondencia de estos agentes o cónsules estadunidenses en Santo Domingo, se analiza el interés y las estrategias de muchos gobernantes dominicanos en anexar o arrendar parte del país a potencias como España, Inglaterra, Francia y la joven Estados Unidos. Se enfoca particularmente el periodo de 1861 a 1865, durante el cual República Dominicana pasa nuevamente a ser parte de España. Se demuestra que Estados Unidos logra mantener una presencia en el país durante esos años y que su interés financiero no disminuye.

Palabras clave:

Anexionistas, dominicanos, agentes comerciales y cónsules, política, gobierno, economía e historia, 1824-1865, Estados Unidos-relaciones exteriores con República Dominicana.

\section{Abstract}

This article studies the competition and rivalry that arose between the major European powers, particularly Spain, and the United States, in their attempts to achieve greater economic and political power in the Dominican Republic in the period from 1844 to 1865 . It highlights the role played by the earliest US "commercial agents" or "consuls" in the country who were confronted with the various European diplomats. The author uses the correspondence between these US agents or consuls in Santo Domingo to analyze the interest and strategies of many Dominican rulers in annexing or leasing part of the country to powers such as Spain, England, France and the young United States. He focuses particularly on the period from 1861 to 1865 , during which the Dominican Republic once again became part of Spain. He proves that the United States managed to maintain a presence in the country throughout this period and that its financial interest did not decline.

\section{Key words:}

Dominican Republic-supporters of annexation, commercial agents and consuls, politics, government, Dominican economics and history, 18241865, United States-foreign affairs with the Dominican Republic.

Fecha de recepción: febrero de 2002

Fecha de aceptación: diciembre de 2002 


\title{
Competencia, rivalidad y anexión en República Dominicana, 1844-1865
}

\author{
José Lee Borges
}

\section{INTRODUCCIÓN}

$\mathbf{E}$ n 1898, mientras las tropas estadunidenses y españolas combatían en un conflicto desigual por obtener la soberanía y el control del Caribe, la entonces joven República Dominicana se declaraba neutral ante tales sucesos de importancia internacional. Lejos de no interesarse por los conflictos de la guerra hispanoamericana, la realidad es que los intereses económicos dominicanos ya estaban empeñados en las compañías estadunidenses. En 1892, el gobierno estadunidense había fundado la San Domingo Improvement Company ${ }^{1}$ exclusivamente para operar en República Dominicana, y en particular para hacerse cargo de la deuda exterior del país. En poco tiempo esta compañía compró la deuda exterior dominicana, que estaba en manos holandesas. Más tarde se apoderó del control de la aduana $y$, paulatinamente, de todos los ingresos del país, incluyendo el Banco

${ }^{1}$ Knight, Americanos, 1980; Tansill, Estados Unidos, 1977; De la Rosa, Finanzas, 1915; Herrera, Finanzas, 1955; entre otros. El estudio que más profundiza sobre San Domingo Improvement Company es bastante reciente, es la tesis doctoral de Vesser, "Remapping", 1997, la cual recientemente se publicó, véase, Veeser, World, 2002.
Nacional. Éstos fueron algunos de los pasos tomados por los estadunidenses en su interés de dominar el Caribe. La compañía no surgió de la noche a la mañana; Estados Unidos necesitó un largo y complejo proceso para asegurar su hegemonía en el otro país. ${ }^{2}$

Este trabajo examina la antesala de ese momento, es decir, el proceso que tuvo Estados Unidos para llegar a dominar económicamente República Dominicana a

${ }^{2}$ Aunque este artículo sólo desea resaltar la presencia estadunidense en República Dominicana o Ia Española de 1844 a 1865 , la realidad es que la relación entre ambos comienza mucho antes, como muy bien señala Tansill, Estados Unidos, 1977, p. 1: "Las relaciones entre Norteamérica y la isla de Santo Domingo comenzaron en los albores del siglo xvin cuando atrevidos capitanes yanquis se aventuraron en los dominios españoles atraídos por incentivos comerciales. Puesto que las islas británicas del Caribe no podían absorber las abundantes exportaciones de las colonias continentales, las necesidades de la economía forjaron nexos coloniales de un carácter más cosmopolita. Este comercio intercolonial estaba en pugna directa con las leyes de la navegación de entonces, pero sus atractivos eran tan fuertes y las recompensas de aquel comercio ilícito tan ricas que las diferencias de raza, religión y nacionalidad fueron apenas tenidas en cuenta. $\mathrm{Ni}$ aún las múltiples guerras que padecía la vieja Europa pudieron destruir estas conexiones." 
fines del siglo XIX. Nuestro estudio comprende desde la llegada de los primeros agentes comerciales estadunidenses en 1847 , hasta la segunda independencia de la república, en 1865. Ponemos énfasis en el panorama político y económico del país y la participación estadunidense en los diversos eventos que se suscitan. Sobre todo destacamos la competencia y lucha entre las potencias internacionales. El análisis se apoya en la correspondencia consular estadunidense en República Dominicana, que nos parece una buena fuente primaria para conocer -y demostrar- el interés genuino y precoz de Estados Unidos en el Caribe. ${ }^{3}$ Esas cartas, a la vez, documentan los eventos del momento, y muchas de las actividades de los otros poderes europeos. Aunque en algunas ocasiones nos referimos a fuentes secundarias muy conocidas, nuestra intención es que el lector se familiarice con la visión estadunidense del periodo y que, a partir de ésta, llegue a sus propias conclusiones.

${ }^{3}$ Aunque no es nuestra intención en este artículo, es preciso señalar que la historiografía estadunidense en su fachada objetiva, ha sido reacia a aceptar la realidad histórica del imperialismo estadunidense. Muchos estudiosos de aquel país tratan de exonerarlo en vez de admitir la agenda oculta y explicar los factores que propiciaron las tendencias imperialistas del siglo XIX. Las citas que usamos en este artículo ayudarán al lector a entender la mentalidad de los funcionarios públicos estadunidenses de la época.
ESTADOS UNIDOS ENVÍA A SUS PRIMEROS

AGENTES COMERCIALES A REPÚBLICA DOMINICANA

Una guerra entre Estados Unidos y España es indispensable este año, y será mejor que España conozca a los americanos aquí, en los campos de batalla lde República Dominicana], que en Cuba. ${ }^{4}$

La isla de La Española, situada entre Cuba y Puerto Rico, fue la primera colonia española en el nuevo mundo. Hoy día está compuesta por Haití en el lado occidental y República Dominicana en el oriental. En 1697, mediante el Tratado de Ryswick, España cedió a Francia una tercera parte del territorio situado en el sector occidental de la isla. En el siglo XVIII, esta colonia francesa, conocida como Saint Domingue, se convirtió en una próspera región, dependiente de la mano de obra esclava africana. Los esclavos, junto con una parte de la población negra libre, se rebelaron para sacar a los franceses de la isla, lo que culminó con la proclamación de la República de Haití en 1804.

En la parte española de la isla, llamada Santo Domingo, la historia era diferente. La prosperidad estaba ausente de la región. Muchos colonos españoles habían partido hacia nuevos territorios recién descubiertos en el continente, llevando consigo a sus esclavos. A principios del siglo XIX, Santo Domingo se encontraba en la miseria. La población mermaba, la

${ }^{4}$ Jacob Pereira a W. L. Marcy, doc. 15, 7 de agosto de 1856, Despatches from United States Consuls in Dominican Republic, 1837-1906, serie T-56. Centro de Investigaciones Históricas, Universidad de Puerto Rico, Recinto Río Piedras (en adelante CIH-UPR-RP-DCSD). 
agricultura comercial era prácticamente inexistente, la ganadería escaseaba y la economía estaba descapitalizada. Su situación era contraria a la de la parte occidental, la cual se mantenía mucho más poderosa económica y demográficamente. En 1822, el ejército haitiano, encabezado por Jean Pierre Boyer, anexa a Santo Domingo; esta unión durará hasta $18444^{5}$

En 1847, Estados Unidos envía sus primeros agentes comerciales a República Dominicana, cuya labor era promover el comercio estadunidense en el país donde radicaban. Los agentes comerciales, que luego pasarán a ser llamados cónsules o cónsules generales, debían esforzarse por crear un ambiente favorable en sus respectivos distritos para atraer y vender mercancía de Estados Unidos, y tenían que enviar correspondencia e informes comerciales y de otros asuntos regularmente al secretario de Estado. Otra de sus tareas era cuidar y ayudar a los ciudadanos estadunidenses que tenían o que planeaban tener negocios en el país correspondiente. ${ }^{6}$

En 1847 comienza a circular la correspondencia de los primeros agentes comerciales estadunidenses radicados en República Dominicana. En esta correspondencia queda plasmado su interés precoz por la isla del Caribe; es aún más evidente el interés por resaltar el valor de la participación de Estados Unidos en la eco-

\footnotetext{
${ }^{5}$ Ésta es la segunda unificación de la isla. La primera ocurrió cuando Toussaint-Louverture entró en Santo Domingo en 1801, cumpliendo los términos del Tratado de Basilea entre Francia y España. En ambas ocasiones, los haitianos abolieron la esclavitud en la parte oriental de la isla. Véase, sobre este particular, Price-Mars, La République, 1953; Moya, Dominación, 1978.

${ }^{6}$ Stuart, American, 1936, p. 350.
}

nomía de República Dominicana. Un ejemplo de esto es el informe enviado por el agente comercial Francis Harrison al secretario de Estado James Buchanan, señalando la participación de los buques en los puertos dominicanos. ${ }^{7}$ Según el informe, durante 1833 llegaron al puerto de Santo Domingo 25 buques estadunidenses, doce de Francia, once ingleses, siete haitianos y cuatro holandeses. En el mismo año, la mayor carga provino también de Estados Unidos, con un total de 3008 toneladas, y desde entonces hasta 1838 , la presencia de buques estadunidenses en Santo Domingo aumenta consistentemente.

En 1843 comienzan a surgir los movimientos separatistas de Santo Domingo en contra de su vecino Haití. ${ }^{8}$ El historiador dominicano Frank Moya Pons señala cuatro distintos movimientos separatistas, tres de los cuales estaban enfocados a recibir ayuda de potencias extranjeras. En primer lugar, había un movimiento separatista proespañol -dirigido por el sacerdote Gaspar Hernández y por Pedro Pamiés-, que buscaba el apoyo en la "Madre Patria". El segundo movimiento buscaba ayuda de Inglaterra. Un tercer grupo, encabezado en su mayoría por experimentados administradores haitianos, quería la ayuda de Francia. El cuarto grupo, dirigido por Juan Pablo Duarte, buscaba la separación pura y simple, sin la ayuda de las potencias extranjeras. Los primeros tres grupos estaban preparados a pagar el

\footnotetext{
${ }^{7}$ Francis Harrison a James Buchanan, doc. 2, 26 de abril de 1847, CIH-UPR-RP-DCSD.

${ }^{8}$ Muchos historiadores señalan que estos movimientos empiezan antes de 1843 . Véase Moya, Dominación, 1978.
} 
apoyo extranjero con beneficios exclusivos de comercio, impuestos y tratados comerciales. A pesar de que durante este periodo existía una presencia activa de un agente comercial estadunidense en Santo Domingo, no se conoce movimiento alguno que buscara ayuda en Estados Unidos para lograr la separación de Haití.

A pesar de la guerra por consolidar la independencia, la economía de la isla no mermó. En 1833 llegaron un total de 64 buques al puerto de Santo Domingo, y en 1837, la cantidad aumentó a 83 buques. Luego de independizarse de Haití en 1844 y de declararse -por segunda ocasión- República Dominicana, la entrada de buques aumentó aún más. En 1849 llegaron a Santo Domingo 130 buques extranjeros, en 1850 hubo 147 , en 1851 fueron 128, y en 1852, 162 buques. Evidentemente ocurrió un aumento en los productos que llegaban a República Dominicana del extranjero. Cabe señalar que los dos puertos de mayor importancia eran Santo Domingo y Puerto Plata.

En 1844, Estados Unidos no dominó la entrada de buques, pero ello no se debió a que disminuyera su interés, sino a que otras potencias aumentaron su presencia. Por ejemplo, en 1852, al puerto de Santo Domingo entraron un total de 162 buques: 38 ingleses, 27 dominicanos, 30 franceses, 20 daneses, 20 holandeses y quince estadunidenses, entre otros. ${ }^{9}$ La

${ }^{9}$ Elliot a Marcy. Information about the island, 1 de marzo de 1854, CIH-LPR-RP-DCSD. Los restantes doce buques son: cuatro italianos, dos de Hamburgo, dos de Prusia, dos [ilegible], uno de España y uno de Suecia. El mismo año, en el puerto de Puerto Plata, el dominio inglés es más evidente: de un total de 162 buques, 82 eran ingleses, con $30 \%$ de todo el tonelaje y $20 \%$ del valor global. demanda de productos en la isla aumenta, así como la cantidad de buques de otras naciones. Las potencias extranjeras comienzan a gestar proyectos para aumentar su participación comercial y política en el país. En 1844 da inicio, entonces, una etapa de lucha y rivalidad entre estos poderes; en otras palabras, comienza la competencia internacional por República Dominicana.

Al finalizar la guerra con Haití, la debilitada República Dominicana se ve obligada a buscar apoyo de todas las potencias extranjeras en contra de posibles invasiones haitianas. En 1849, el gobierno dominicano le solicita protección al cónsul francés en Santo Domingo, a lo que Francia responde enviando 150 hombres desde Martinique, colonia francesa en el Caribe. El cónsul inglés reacciona oponiéndose absolutamente a la ayuda de Francia, asegurando que puede conseguir un respaldo mayor de la corona inglesa. El agente comercial estadunidense Jonathan Elliot asegura que la verdadera razón por la cual Francia e Inglaterra ofrecían apoyo era la de obtener paulatinamente la posesión de la bahía de Samaná. El gobierno dominicano también solicitó ayuda a Estados Unidos y llegó más lejos que con Francia e Inglaterra, ya que pidió que se considerara la anexión. El agente Elliot respondió "que él sólo estaba autorizado a velar por los intereses comerciales estadunidenses", ${ }^{10}$ a diferencia de los dos cónsules europeos, a quienes sus gobiernos

${ }^{10}$ Jonathan Elliot a Secretary of State, doc. 15, 2 de mayo de 1849, CIH-UPR-RP-DCSD. En esta correspondencia, Elliot también señala que era probable que una delegación fuera enviada desde la isla a Washington, con el objetivo de reconocer la independencia de la isla. 
les habían dado poder para realizar negociaciones.

La práctica del gobierno dominicano de buscar apoyo militar y político continuó. En los años subsiguientes a su independencia, República Dominicana tuvo como objetivo hacer tratados de amistad y comercio con varias potencias europeas y Estados Unidos. El 6 de marzo de 1850, República Dominicana firmó con Inglaterra el Tratado de Paz, Amistad, Comercio y Navegación. Este tratado fue analizado de dos formas distintas por Estados Unidos. Primero, era una manera de eliminar la amenaza de invasión. Segundo, representaba un problema comercial, ya que afectaba a los estadunidenses en el país. Al respecto, el agente comercial Elliot señala al secretario de Estado Daniel Webster que:

Nosotros tenemos el control de la mayor parte del comercio del país y, sin embargo, el tratado con Inglaterra lo está destruyendo. Nuestros buques pagan tres veces más la cantidad de tonelaje y cargos de puertos que lo que pagan los buques ingleses. Los ingleses creen que es justo reconocer al país como república a cambio de un tratado comercial que destruya nuestra preponderancia. ${ }^{11}$

El agente Elliot exigió que esta situación la considerara el gobierno de Estados Unidos y, sobre todo, señaló que había que tomar medidas al respecto.

El conflicto que se desarrolla en República Dominicana entre los países europeos y Estados Unidos se puede ver como una lucha entre varias potencias desarrolladas y una potencia en desarrollo. Aque-

11. Jonathan Elliot a Daniel Webster, doc. 26, 29 de septiembre de 1850 , CIH-UPR-RP-DCSD. llas que en siglos pasados se dividieron prácticamente todo el Caribe y las regiones cercanas, serán los líderes de vanguardia y representarán la experiencia. Estados Unidos fungirá como el joven guerrero con sed de victoria, respeto y expansionismo.

El 1 de abril de 1852 se firmó el Tratado de Amistad, Comercio y Navegación entre República Dominicana y Dinamarca, basado en principios de la más perfecta reciprocidad. Este tratado y el anterior, firmado con Inglaterra, fueron motivando a Estados Unidos a realizar uno.

Sin embargo, el tratado más importante que realiza República Dominicana durante este periodo es, sin duda, con España. Éste se pactó en 1856 y será la causa de muchas confrontaciones entre Estados Unidos y España. Antonio M. Segovia, encargado de Negocios Españoles y cónsul general en Santo Domingo, quería establecer pautas económicas para su gobierno, y tenía el poder para hacerlo. Según él, el artículo 7 del tratado firmado por el gobierno dominicano con España le concedía poderes para negociar en el país. Esta cláusula establecía además que los extranjeros no podían adquirir ninguna parte del territorio de República Dominicana.

Mientras tanto, el presidente Pedro Santana le prometió al agente comercial Elliot que tan pronto llegara a la capital -ya que se encontraba con el ejército en el campo de batalla- trabajaría con la ratificación de su tratado. A esto añadió que, cuando se calmara la situación, trabajaría sobre un segundo tratado para arrendar la bahía de Samaná a los estadunidenses. ${ }^{12}$

12 Jonathan Elliot a W. L. Marcy, doc. 1, 6 de enero de 1856 , CIH-UPR-RP-DCSD. 
Según lo describe el agente comercial Elliot, el segundo tratado no sería muy diferente del primero. Aseguró que en este nuevo tratado se incluiría todo lo que había propuesto el general William Cazneau, uno de los primeros inversionistas estadunidense en llegar a La Española, quien siempre contó el respaldo del gobierno de Estados Unidos. ${ }^{13}$

Los dos tratados con Estados Unidos se efectuaron, a pesar de las imposiciones y de negativas de los cónsules europeos, especialmente de Segovia, de evitarlo. Dice Elliot:

He observado que los cónsules de España, Inglaterra y Francia se han opuesto fuertemente a que nuestro país realice tratados con esta república. El tratado, como actualmente se lee, es sustancialmente el mismo que fue firmado el 5 de octubre de 1854 . No abarca todo lo deseado, pero es lo mejor que pude realizar bajo las circunstancias actuales.

La seguridad completa de nuestros ciudadanos y su propiedad ha sido mi principal meta, cuidando que nada se pueda percibir como prejuicio a las leyes locales y de nuestros estados. Las dificultades que nuestros cónsules siempre han tenido en países españoles, en cuanto a barcos naufragados y la propiedad de nuestros ciudadanos muertos son la causa de que insista en este particular. Finalmente, esta república es, por el tratado, completamente abierta y segura para las empresas e industrias de nuestros ciudadanos. Espero que el mismo cuente con su aprobación. ${ }^{14}$

${ }^{13}$ Para conocer más sobre él, véase García y Lee, "Consular", 1998.

${ }^{14}$ Jonathan Elliot a W. L. Marcy, doc. 6, 22 de marzo de 1856 , CIH-UPR-RP-DCSD.
Entre los mecanismos del cónsul Segovia para evitar la ratificación del tratado con Estados Unidos estuvo el de apoyarse en el artículo 7 de su tratado; esto lo unía simbólicamente al vecino Haití, el cual tenía los mismos ideales sobre la no posesión de tierras por extranjeros. Además, el 19 de julio de 1856, Segovia le ofrece al presidente Santana un préstamo del gobierno español, con tal de que dilatara la ratificación del tratado con Estados Unidos de 1854. Él se haría responsable de cualquier cuestionamiento por parte de los estadunidenses sobre la ratificación. Finalmente, Segovia ofreció al gobierno dominicano un protectorado español -incluida cierta cantidad de tropas terrestres y navales- en caso de amenaza de guerra.

La conducta del cónsul español Segovia era sin duda agresiva. Si Santana no aceptaba sus ofertas, él se dedicaría a destruir al gobierno presente y crear una guerra, particularmente en contra de todas aquellas personas que apoyasen el tratado con los estadunidenses. Para gobernar traetía al presidente anterior, Buenaventura Báez, a quien consideraba un negro importante y antiestadunidense. Segovia comenta irónicamente que prefiere salvar al país de los haitianos que de los estadunidenses. ${ }^{15}$

Paulatinamente, el gobierno español fue asentando su control. En 1856 se anuncia el establecimiento de un periódico español llamado Isabella Segunda, el cual tenía la labor de crear interés y respeto hacia el gobierno español. Esta actitud se iba cultivando de otras maneras, por ejemplo, la de obligar a los ciudadanos dominicanos a saludar a los barcos y la bandera española.

15 Jonathan Elliot a W. L. Marcy, doc. 14, 19 de julio de 1856, CIH-UPR-RP-DCSD. 
Ante las actividades del cónsul Segovia, el agente comercial estadunidense no mostró timidez alguna, sino todo lo contrario. Exhortó al gobierno estadunidense a actuar agresivamente y hasta cierto punto a prepararse para una confrontación con España:

Les aseguro que en estos momentos Estados Unidos puede obtener lo que desee de este gobierno. Podemos establecer una base naval donde queramos y bajo nuestros propios términos, así como ayuda y asistencia de los habitantes. Sólo tenemos que actuar. Enviando dos o tres buques de guerra, todo podrá arreglarse sin dificultades entre Estados Unidos y otra potencia.

Si Estados Unidos determina establecer una base naval, abrirá una gran riqueza para sus habitantes; de igual modo, asegurará la independencia y tranquilidad de la república. No hay tiempo que perder, en este momento el gobierno está destruido, la república se está perdiendo y, si no actuamos, se afectarán la presencia, comercio e interés general estadunidense. ${ }^{16}$

El estadunidense Jacob Pereira, quien ejercía como agente comercial interino, insistía también en la importancia de una intervención de las tropas estadunidenses: "Si el gobierno de Estados Unidos desea asegurar y proteger sus intereses en este país, no hay tiempo que perder". ${ }^{17}$ Las declaraciones del cónsul Segovia al respecto, directas y concisas, no tardaron: "Una guerra entre Estados Unidos y España es indispensable este año, y será mejor que España conozca a los americanos

${ }^{16}$ Ibid.

${ }^{17}$ Jacob Pereira a W. L. Marcy, doc. 15, 7 de agosto de 1856 , CIH-UPR-RP-DCSD. aquí, en los campos de batalla [de República Dominicana], que en Cuba". ${ }^{18}$

La belicosa actitud de Segovia no sólo era en contra de Estados Unidos, sino en contra de todas aquellas potencias que desearan poseer territorios o cualquier ventaja en la República. Los cónsules de potencias europeas pidieron al gobierno español la remoción del cónsul Segovia. El cónsul francés declaró que Segovia no podía impedir, ni estar en contra de ningún tratado que realizara República Dominicana, diciendo que: "República Dominicana es libre de hacer tratos con cualquier nación amiga". ${ }^{19}$

El plan de Segovia era formar una raza de dominicanos negros que se convirtieran en españoles y albergaran odio hacia los blancos dominicanos - que se encontraban en el poder entonces-, hacia los franceses e ingleses, que en su mayoría eran blancos y, sobre todo, hacia todos los estadunidenses. En cierto modo, Segovia partía de una idea que no estaba muy lejos de la realidad: el pueblo dominicano estaba siendo gobernado por dominicanos blancos y la mayor parte de la industria y comercio estaba en manos blancas, mientras que los negros luchaban en la guerra contra Haití o trabajaban por casi nada en las tierras y en los cortes de madera. Para liderar este grupo, era necesario un gobernante negro dominicano, y quién mejor que Buenaventura Báez. De hecho, las negociaciones para traer a Báez se estaban realizando; éste residía en St. Thomas desde 1832, cuando fue expatriado por el propio Santana, quien será el mismo que gestione su regreso.

\footnotetext{
${ }^{18}$ Ibid.

${ }^{19}$ Jacob Pereira a W. L. Marcy, doc. [ilegible], 11 de noviembre de 1856, CIH-UPR-RP-DCSD.
} 


\section{SECUENCIG}
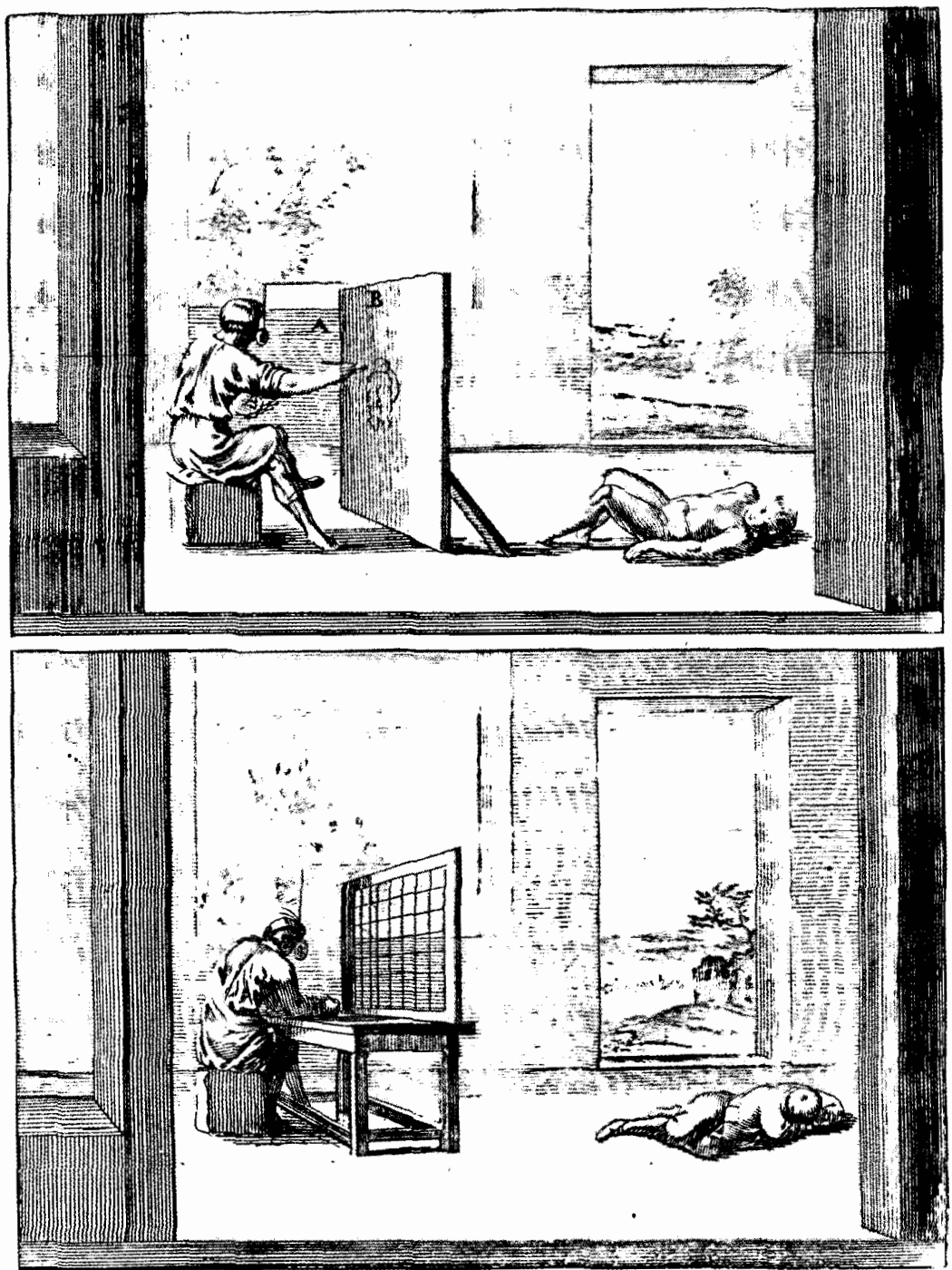
Estados Unidos se encontraba en desventaja en el área del Caribe, ya que no tenía posesiones. El cónsul Elliot justificaba de todas las formas posibles la idea en que Estados Unidos se apoderara de República Dominicana. La postura de estos cónsules muchas veces era extremista y bélica, aunque no tenían el poder de tomar decisiones contundentes:

Denme poder, dejen que el comodoro Paulding venga conmigo, con dos buques de guerra, y en este momento realizaré todo lo deseado. España, Inglaterra y Francia objetarán. Ellos tienen el mismo derecho que nosotros, pero no la necesidad. Ellos poseen Cuba, Jamaica y Martinica como estaciones navales. No hay nada inusual o impropio en tener una estación naval en esta hermosa bahía; con mucha probabilidad aparecerán objeciones, las cuales terminarán en nada. Estoy firmemente convencido que al terminar las negociaciones, las potencias europeas verán claramente que no tienen el derecho de interferir con nosotros en este acontecimiento. $^{20}$

Segovia, para realizar sus planes, necesitaba sacar del poder al general Santana. Gradualmente fue logrando su cometido. El 27 de noviembre de 1856, mediante mandato del señor Segovia y de todos los opositores al gobierno de Santana, se publicó un artículo en el semanario político La Acusación. ${ }^{21}$ En sus ediciones número 1 y 2 , se atacó la política de gobierno del general Santana, culpándola de toda la ruina del país. Por esta acusación, su vida co-

\footnotetext{
${ }^{20}$ Jonathan Elliot a W. L. Marcy (confidencial), 10 de septiembre de 1856, CIH-UPR-RP-DCSD.

${ }^{21}$ Este semanario fue encontrado en CIH-UPRRP-DCSD, y la noticia aparece firmada por el cónsul español Segovia.
}

menzó a correr peligro, lo cual sin duda fue uno de los motivos para su renuncia. Los agentes comerciales estadunidenses, quienes conocían todo el trayecto de Santana, lamentaron su salida. Este general era quizás en ese momento el mejor aliado de los estadunidenses, ya que había ratificado positivamente en dos ocasiones el Tratado de Comercio con Estados Unidos en contra de los intereses europeos. Era la esperanza de los intereses estadunidenses en República Dominicana y su salida forzosa fue condenada por el agente Elliot:

Él, quien ha rechazado a los haitianos en cada caso de invasión. Él, quien aspira a una población blanca. Y, finalmente, él, quien fue el único hombre que se atrevió a que un tratado con Estados Unidos pasara al Senado, es hoy aplastado por el partido AntiAmericano, por el partido de Buenaventura Báez. Y ¿por qué? Porque él apoyó el tratado y la causa americana. ${ }^{22}$

Para el agente Elliot, los estadunidenses no debían quedarse con las manos cruzadas, ya que le debían mucho al general Santana. En múltiples ocasiones pide que se tomen medidas al respecto, pero sin mucho efecto.

La política de difamación realizada por los españoles y por todos aquéllos a favor de sacar del poder a Santana, también fue dirigida contra los estadunidenses. En una carta, el agente Elliot informa al secretario de Estado cómo se estaba corriendo el rumor de que el país sería atacado por filibusteros estadunidenses. Éstos, según el rumor, estarían apoyados por el gobierno de Estados Unidos y actuarían para apoderarse de República Dominicana en fa-

${ }^{22}$ Jonathan Ellior a W. L. Marcy, doc. 22, 29 de noviembre de 1856, CIH-UPR-RP-DCSD. 
vor del general Santana. Para la rumorada invasión, ya se había pedido el apoyo militar de las potencias europeas: Inglaterra, Francia y, por supuesto, España.

Estos hechos amenazantes no quedaron sólo en papel, sino que se tradujeron en eventos violentos entre dominicanos y estadunidenses. El 7 de marzo de 1857, a 20 millas del puerto de Santo Domingo, el buque estadunidense Charles Hill colisionó con el buque dominicano Packet. Según los informes, el buque dominicano recibió graves daños, pero para el capitán estadunidense Albert Smith fue un mero accidente. Sin embargo, el Charles Hill fue confiscado. A su capitán se le obligó a abandonar el buque $y$, además, a pasar 20 años de cárcel o pagar la suma de 3200 dólares. Según el agente comercial Elliot, esto se debŕa a la falta de justicia hacia los extranjeros, en especial a los estadunidenses: "En este país no hay justicia en los tribunales para los extranjeros, especialmente americanos". ${ }^{23}$ Según las acusaciones del gobierno dominicano, el buque estadunidense provocó el accidente de forma incitante. Para Elliot, esta determinación tuvo el único propósito de asegurar el control español y exigir respeto a los estadunidenses:

El actual gobierno está enteramente bajo el control de España, Inglaterra y Francia. Ellos no desean que nuestros ciudadanos tengan ningún interés aquí, y ahora están confabulando con Haití, por el oeste. ${ }^{24}$

Elliot no estaba muy lejos de la verdad. El gobierno dominicano, apoyado

${ }^{23}$ Jonathan Elliot a W. L. Marcy, doc. 7, 7 de marzo de 1857, CIH-UPR-RP-DCSD.

${ }^{24} \mathrm{Ibid}$. por las potencias europeas, en especial España, se encargó de manchar la imagen de los estadunidenses. El 26 de abril de 1857 se publica, en el número 34 del Eco del Pueblo, el artículo "Reclamación pelegrina", en el cual, en otras palabras, se señala que es absurdo que los estadunidenses se declaren inocentes y pidan indemnización, cuando son los únicos culpables.

En ese mismo informe, Elliot señala al secretario de Estado que su esposa fue víctima de la poca seguridad con que contaban los extranjeros en el país. Un jefe de los oficiales del ejército apuntó con una carabina a la señora Elliot, y si no hubiera sido por la intervención del propio Elliot, el oficial hubiera disparado. Como resultado, se le pidieron respuestas al señor José Delmonte, encargado del ejército. El clima belicoso se hacía sentir en todos los ámbitos, tanto en las revueltas como en los conflictos personales de todas las potencias en el país.

Las ideas del cónsul Segovia se fueron realizando paulatinamente. La idea de la llegada de Báez era desagradable para muchos, y causó graves conflictos internos en el país, incluyendo problemas en las áreas comerciales más importantes. El 1 de julio de 1857 ya se sabía de una revuelta en Santiago. En el Cibao, la región más importante para la industria del tabaco, se dio también un grito de alerta en contra del régimen de Báez. Ahí se publicó el artículo "Manifiesto de los pueblos del Cibao y de las causas que lo han impulsado a reasumir sus derechos", que denuncia los abusos del gobierno contra los habitantes de esa zona, donde se había violado la libertad individual, y se había apresado y juzgado arbitrariamente a los ciudadanos. Expresaba, además, que en el transcurso de catorce años los habi- 
tantes del Cibao habían dado prueba de lo que puede soportar un pueblo.

Por otro lado, de acuerdo con el agente comercial Elliot, los seguidores de Báez estaban perdiendo fuerza. Según señala en un informe del 23 de noviembre de 1857, ya la cantidad de soldados que éste poseía era mucho menor a la de Santana. Aunque contaba con el apoyo de España y Francia, a Báez la entrada no le era tan fácil como esperaba, a pesar de que en mayo de 1858 realizó un bloqueo sumamente efectivo en Puerto Plata, para lo cual adquirió tres nuevos buques de guerra que lo llevaron a poseer un total de siete.

A finales de 1858, el gobierno haitiano, representado por el francés Maxime Baybaud le hizo una proposición al presidente Santana. Según Baybaud, quien anteriormente se había desempeñado como cónsul general de Francia en Haití, el estado inestable y la amenaza de las potencias europeas colocaban en peligro la independencia de la república. Le ofrecía al país unirse temporalmente a Haití con la única razón, según él, de salvar la independencia de República Dominicana. ${ }^{25}$ Según Elliot, las verdaderas intenciones del señor Baybaud eran alejar toda esperanza de negociación por parte de Santana con el gobierno de Estados Unidos. Elliot acusó y culpó al señor Baybaud de crear en la isla una guerra para luego ofrecer este pacto que sólo beneficiaría a Haití.

En una reunión de Elliot con el presidente Santana, este último le confirmó su gran deseo de establecer unas relaciones sólidas y fructíferas con el gobierno de Estados Unidos. Elliot señala que:

25 Jonathan Elliot a Lewis Caps, doc. 10, 21 de octubre de 1858 , CIH-UPR-RP-DCSD.
Santana ha expresado un fuerte deseo de hacer los acercamientos más íntimos y amistosos entre esta república y Estados Unidos, por tratados y todas las ventajas posibles que nos pueda ofrecer. Si Estados Unidos desea, éste es el momento adecuado. ${ }^{26}$

La carta de Elliot iría acompañada de la noticia sobre una concesión hecha por el gobierno dominicano a una compañía compuesta por ingleses y franceses, cediéndoles los derechos para explotar todas las minas en República Dominicana. ${ }^{27}$ Esta concesión muestra que varias potencias europeas continuaban fijando sus intereses en República Dominicana, y que se había desatado una carrera en busca de concesiones y ventajas.

Para esta misma fecha se anuncia que el gobierno dominicano había despachado a un agente especial a Europa, con la misión de solicitar un préstamo. La idea era conseguir la cantidad de 5000000 de dólares para prepararse contra cualquier ataque por parte de los haitianos. Para conseguirlo, se ofrecerían a cambio todas las ventajas del país.

La posible guerra entre la República y Haití muchas veces fue considerada absurda; para muchos, los dominicanos eran

26 Ibid.

${ }^{27}$ Se establecieron varias condiciones para esta concesión. Se le pagaría al gobierno dominicano 3000000 de francos durante el periodo de tres meses, luego de firmar el contrato, o de lo contrario quedaría nulo. Las operaciones tendrían comienzo a lo sumo en tres años. El gobierno dominicano recibiría $10 \%$ de la producción bruta de las minas. Esta concesión se refería a las minas de tierras en propiedad del gobierno de República Dominicana; otras estaban en manos privadas, las cuales señala el agente Elliot, estaban dispuestas para los estadunidenses que quisieran invertir en ellas. 
superiores a los haitianos. Las leyes de los dominicanos eran vistas por las potencias europeas y por Estados Unidos como sumamente modernas y liberales, cosa que los hacía una raza más inteligente.

Llama la atención un escrito que aparece en esta época, titulado Idea del valor de la isla española o sea Santo Domingo, de Antonio Sánchez Valverde. Este panfleto, como lo denominó el agente Elliot, era para asustarse, ya que, según él, colocaba a los españoles en una posición preponderante en la isla. ${ }^{28}$

Estos acontecimientos, conjuntamente con los que ocurrían en Estados Unidos previos a la guerra civil, afectaron el comercio de Estados Unidos con la República. Según informes comerciales, durante el periodo del 7 de julio de 1857 al 12 de junio de 1858 -casi un año-, sólo dos buques estadunidenses llegaron al puerto de Santo Domingo. El comercio entre ambos países prácticamente cesó. En cuanto a Puerto Plata, se informó que sólo 17 buques estadunidenses tocaron el puerto dominicano, cargando 2500 toneladas.

Las dificultades que confrontó el gobierno de Santana durante las revueltas de 1858 fueron tantas y tan graves, que él y sus amigos decidieron resucitar la vieja idea de recurrir al auxilio de una potencia

${ }^{28}$ Este libro fue publicado en 1853 por la Imprenta Nacional José de Jesús Castro. Su primera edición es de 1785, de Madrid, con el nombre Idea del valor de la isla española, y utilidades que de ella puede sacar su monarquía. El agente Elliot hace un llamado particular sobre los capítulos 6,26 y 27 . El capítulo 6 se refiere a todas las maderas útiles que produce la isla, el 26 es sobre las minas y la ventaja de valor que le da ésta a la parte francesa de la isla. El capítulo 27 es en su totalidad de la bahía de Samaná y los perjuicios que seguirán de cederla a otra nación. extranjera que ayudara a resolver los problemas de estabilidad política y seguridad económica.

LOS ESTADUNIDENSES: ESPECTADORES Y VÍCTIMAS DE LA ANEXION FORZADA DE República DOMinicana a España

[La insistencia en la anexión] lo que ha hecho es destruir y arruinar al país y su gente por el (supuesto) bien del honor. ${ }^{29}$

La anterior cita del cónsul estadunidense en República Dominicana describe la situación y las condiciones del país en los momentos que los dominicanos luchaban por restaurar su gobierno de los españoles. El periodo de 1861 a 1865 se conocerá como el de los años de la anexión a España, y 1865 , en particular, como el año de la restauración.

A partir de 1860, se da en República Dominicana una situación paradójica en que los fuertes ponen a prueba a los débiles. Estados Unidos será sólo un espectador y se conformará con ver cómo ocurren los acontecimientos. Para este periodo surge la figura de William Seward, que podríamos considerar de las más importantes en el proceso de incorporación, influencia, inversión e intervención de Estados Unidos en el Caribe. Durante esta etapa, Seward desea conseguir la unión de República Dominicana a Estados Unidos, mediante una guerra con los países europeos. El presidente Lincoln, por su parte, pensaba que una causa nacional de guerra unificaría al ejército y consolidaría la unidad de Estados Unidos:

${ }^{29}$ William Jaeger a William Seward, doc. 8, 28 de enero de 1864, CIH-LPR-RP-DCSD. 
Yo exigiría categórica e inmediatamente explicaciones a España y Francia. Yo trataría de lograr explicaciones de Gran Bretaña y Rusia, y enviaría agentes a Canadá, México y América Central para despertar en este continente un vigoroso espíritu de independencia continental contra la intervención europea. ${ }^{30}$

Pero la situación por la que atravesaba Estados Unidos no era la más conveniente para concretar las intenciones masivas y agresivas de Seward. La guerra civil entre norte y sur de Estados Unidos, que duraría de 1861 a 1865 , se encontraba a punto de estallar.

En 1858 los problemas económicos propician ideas de anexión con Estados Unidos. Ya en República Dominicana se hablaba de los adelantos americanos, "con vivo placer [...] de sus ferrocarriles y vapores, del fomento de la educación popular, de la abrogación o aflojamiento de las antiguas leyes opresivas que regulaban el comercio y la industria". 31

Es curioso que el general Santana, teniendo tanto interés en establecer vínculos estrechos con Estados Unidos, accediera a anexar República Dominicana a España. Hemos visto que en múltiples ocasiones el general Santana deseó establecer lazos, mediante el agente comercial Elliot, con Estados Unidos. Por su parte, el agente Elliot había insistido en que Estados Unidos enviase uno o dos buques de guerra a costas dominicanas para lograr el respeto de las potencias europeas.

En marzo 21 de 1859, Elliot, en correspondencia enviada a Caps, secretario

${ }^{30}$ J. G. Nicolay y John Hay, Abrabam Lincoln, citado en Tansill, Estados Unidos, 1977, p. 255.

${ }^{31}$ Ibid., p. 262. de Estado, deja ver su descontento con la conducta de Estados Unidos. Según Elliot, es inadmisible que tras tantas sugerencias que éste le ha hecho al gobierno que representa, no hayan enviado un agente especial que investigue los verdaderos intereses de República Dominicana. Era un momento particularmente apropiado para actuar, dado que ambos contratos importantes con Francia, el de las minas y la solicitud de préstamo de 5000 000, habían quedado nulos y sin efecto. Por otro lado, ya se sabía de empresarios estadunidenses que estaban invirtiendo en el país. Para octubre de 1859, el agente comercial notificó que existían grupos de estadunidenses en busca de oro cerca de Santiago. Sobre este grupo, el agente no tenía mucho conocimiento, pero no se había informado de ningún daño o atentado contra ellos.

En esta misma correspondencia, el agente Elliot expresa que no era Samaná la única zona atractiva en República Dominicana para una base naval y puerto de defensa. Elliot identifica la bahía de Ocoa, situada a 16 millas al oeste de Santo Domingo, describiéndola en los siguientes términos: "es una de las más hermosas y finas que he visto en mi vida, con excelente agua para beber". ${ }^{32}$ En otras palabras, según Elliot, era mucho lo que se podía ganar y poco lo que se perdía si sólo Estados Unidos intentaba negociar verdaderamente con el gobierno dominicano. Cabe señalar que individuos estadunidenses, como el general William Cazneau, llevaban en el país seis meses sin decir nada de sus negociaciones ni de lo que estaba haciendo. Elliot estaba seguro de

${ }^{32}$ Jonathan Elliot a Lewis Caps, doc. 4, 21 de marzo de 1859 , CIH-UPR-RP-DCSD. 
que Cazneau no había concretado los negocios para los cuales se le había enviado, y más bien aprovechaba, de manera individual, las oportunidades que se le presentaban. ${ }^{33}$ Veía esto como el fracaso del futuro de los inversionistas y la presencia de Estados Unidos en República Dominicana, ya que cada vez la participación de las potencias europeas, en especial la de España, se consolidaba más.

William Seward envía una carta al señor Gabriel Tassara, embajador español en Washington, en la que el secretario de Estado estadunidense protesta contra la aún no confirmada intervención española en República Dominicana. ${ }^{34}$ La respuesta de Tassara no se hizo esperar: señaló que habían ido a salvar vidas extranjeras, principalmente españolas. Para muchos historiadores, como Jaime de Jesús Domínguez, la actitud provocadora de Seward y el posible conflicto entre Estados Unidos y España, tenían como objetivo calmar los ánimos y descontentos entre la Unión y la Confederación y evitar la guerra civil estadunidense. ${ }^{35}$

La anexión de República Dominicana a España se concreta en 1861. Los españoles estaban firmes en recuperar al país y más aún de la forma tan fácil que se le presentaba. ${ }^{36}$ El 22 de marzo de 1861 , el

\footnotetext{
${ }^{33}$ Jonathan Elliot a Lewis Caps, doc. 27, 17 de diciembre de 1859, CIH-UPR-RP-DCSD.

${ }^{34}$ Domínguez, Anexión, 1979, p. 141.

${ }^{35}$ Ibid., pp. 140-141.

${ }^{36} \mathrm{El}$ gobierno dominicano estableció unas bases antes de sellar su incorporación a la antigua "Madre Patria". Primero, no se podía restituir la esclavitud en el territorio dominicano. Segundo, se debía considerar el territorio dominicano como una provincia de España, con los mismos privilegios y derechos que los otros territorios. Tercero, el gobierno español
}

agente comercial Elliot señala que la bandera dominicana había sido sustituida por la de España, y añade que esa parte de la isla -refiriéndose a que la otra parte la ocupa Haití- se había convertido en una provincia de España, y en consecuencia estaba bajo su dominio. ${ }^{37} \mathrm{La}$ presencia y el control de los españoles en República Dominicana vinieron acompañados de muchos cambios significativos. Trajo consigo la llegada de miles de tropas españolas, la mayoría proveniente de Cuba y Puerto Rico, y muchos funcionarios de mayor jerarquía. Samaná fue invadida por miles de tropas, en su mayoría compuestas de ingenieros que preparaban un sistema de fortificación y explotación de recursos. Según el agente comercial estadunidense, alrededor de 1000 personas estaban trabajando en la zona de la bahía de Samaná. La frontera con Haití fue el otro punto estratégico que los españoles tomaron. Alrededor de 6000 soldados fueron colocados en esta parte.

La anexión a España fue recibida con gran regocijo en un principio. "Todos los habitantes aparentan estar contentos y satisfechos, todo transcurre sin mayores dificultades", ${ }^{38}$ informó el agente Elliot. La tierra empezó a cobrar valor, y se comenzaron a restaurar muchos de los destrozos

tenía que emplear la mayor cantidad posible de funcionarios dominicanos en el gobierno. Cuarto, el nuevo régimen ayudaría a amortiguar todo el papel moneda existente en el país. La quinta y última cláusula decía que los españoles tenían que reconocer todas las actas y leyes establecidas por el gobierno dominicano desde 1844.

${ }^{37}$ Jonathan Elliot a Honorable Secretary of State, doc. 2, 22 de marzo de 1861, CIH-UPR-RP-DCSD.

${ }^{38}$ Jonathan Elliot a William Seward, doc. 7, 27 de junio de 1861, CIH-UPR-RP-DCSD. 
causados por las revueltas con los haitianos, que nunca se habían restaurado. Sobre las tarifas que regirían, se establecieron en un comienzo las mismas que en la isla de Cuba. El ejército se mantuvo bajo el control español con una paga mínima. Sin embargo, la escasa población de República Dominicana afectó los proyectos infraestructurales que los españoles deseaban realizar. La mano de obra africana era de igual forma muy limitada en este periodo. El clima era muy distinto al de España, por lo cual muchos españoles no llegaban a acostumbrarse.

La llegada de los españoles no desalentó al agente comercial estadunidense William Jaeger, quien aseguraba que República Dominicana ofrecía mucho más que la bahía de Samaná. Los españoles habían concentrado todo su esfuerzo en esta península, pero Jaeger señaló que Puerto Plata era otro punto estratégico, digno de consideración por los inversionistas: "Nunca he observado una tierra más bella y fértil. Las montañas son ricas en madera valiosa y minerales de todo tipo, están vestidas en ricas verduras y tienen todo lo necesario para criar ganado." 39

Esta nueva etapa que experimentó el país se reflejó en todas los ámbitos. Muchas posesiones codiciadas por Estados Unidos eran traspasadas a los españoles con plena autoridad y poder. El 5 de abril de 1861 se le concedió a don F. Fors, un coronel catalán, la isla de Alta Vela, antes una posesión estadunidense. Los españoles se opusieron mucho a su toma inicial por los estadunidenses, y en 1860 el gobierno dominicano los expulsó. Una vez que los

39 William Jaeger a William Seward, doc. 12, 1 de abril de 1862, CIH-UPR-RP-DCSD. españoles se establecen en la isla, hacen el traspaso a manos de Fors, como método de protección y señal de control y poder.

Después de la anexión a España, las cosas no fueron tan fáciles como esperaba el general Santana ${ }^{40}$ Primero, su idea de mantener el poder absoluto se desvaneció. Los españoles paulatinamente fueron desplazando a los funcionarios locales del gobierno con los de ellos, la mayoría venida de islas vecinas como Cuba y Puerto Rico. Ya para agosto de 1861, el poder de Santana era mínimo y prácticamente se encontraba solo; en enero de 1862 renunció a su cargo aduciendo enfermedad. La salida para Santana fue agridulce: por un lado, no pudo mantener el poder que deseaba, o sea, el control absoluto, y por lo tanto renunció; por otro, realizó sus deseos de ver al país en manos de la "Madre Patria", ideal que siempre deseó.

La salida de Santana dijo mucho a Estados Unidos, ya que de una manera u otra reflejaba el descontento de prácticamente todos los habitantes. Este descontento gradualmente fue tomando fuerza, principalmente en las provincias de Santiago, Moca, la Vega, y llegando hasta el Cibao y Azua. En una entrevista, el agente Jaeger dice lo siguiente: "Ellos dicen que no necesitan ayuda para llevar a los españoles hacia el mar. Lo único que piden es quedarse con su puerto y no dejar que España lo bloquee."41 La mayor parte de las personas estaba a favor de que explotara una revolución en contra del régimen español establecido. Sin embargo,

\footnotetext{
40 Para más detalles sobre este evento, véase Bosch, Guerra, 1982.

4l William Jaeger a William Seward, doc. 21, 3 de julio de 1862, CIH-UPR-RP-DCSD.
} 
en este momento no existía consenso general o uniformidad en cuanto a qué estrategia seguir. Por otra parte, muchos deseaban de alguna manera recibir ayuda de Estados Unidos, que se encontraba iniciando su guerra civil: "Sus plegarias son que los problemas en Estados Unidos pronto terminen, puesto que es la única potencia en la tierra en la cual pueden buscar protección y justicia." 42

Para los españoles, el resultado de la anexión no fue el esperado. Los españoles esperaban equivocadamente encontrar gente muy parecida a ellos, tanto en color de piel corno en sus hábitos y costumbres. Muchos españoles, al percatarse del color oscuro de los dominicanos, insinuaban que deberían de ser esclavos en Cuba y Puerto Rico, donde aún se practicaba la esclavitud. Este rumor rápidamente se comenzó a dispersar por el país, y causó, además del rechazo dominicano, un conflicto entre los mismos dominicanos, ya que los más claros se alejaban de los oscuros para no ser confundidos. Además, se prohibió a los militares dominicanos utilizar el uniforme especial español, lo que hirió profundamente el amor de estas personas a su nueva "Madre Patria". Poco a poco el encanto se fue perdiendo para ambas partes, dominicanos y españoles, que no encontraron en la anexión precisamente lo que esperaban. ${ }^{43}$

Otra cosa que causó desilusión sobre la anexión fueron las diferencias marcadas entre las prácticas religiosas. La llegada del arzobispo Bienvenido de Monzón trajo muchos conflictos con el sistema ecle-

\footnotetext{
${ }^{42}$ Ibid.

${ }^{43}$ Sobre las razones del fracaso de la anexión a España véanse las obras de Moya, Manual, 1981 y Cassá, Historia, 1982.
}

siástico, pues tan pronto llegó se propuso modificar las costumbres de los dominicanos, que él consideraba en deplorable estado. En República Dominicana se practicaba el concubinato; los matrimonios ${ }^{44}$ eran muy escasos, por no decir casi inexistentes. Las nuevas órdenes religiosas prohibían toda adoración o práctica religiosa fuera de la iglesia católica romana. El incumplimiento de esta ley resultaría en la expulsión del infractor fuera de la isla. ${ }^{45}$ Según el periódico oficial, Gaceta de Santo Domingo, la persona que celebrara actos públicos de un culto fuera de la religión católica, apostólica, romana sería castigada con la pena de exilio temporal. ${ }^{46}$ Esta orden atentaba particularmente en contra de muchos estadunidenses negros que se habían establecido temprano en

${ }^{44}$ Instituidos o reconocidos por la Iglesia.

is William Jaeger a William Seward, doc. 6, 3 de marzo de 1863, CIH-UPR-RP-DCSD.

${ }^{46}$ Gaceta Oficial de Santo Domingo, 26 de febrero de 1863 , año 3, núm. 166. En esta publicación se presenta el código penal y los delitos contra la religión. Aquí presentamos unas cuantas de ellas para que los lectores interesados puedan tener una idea más clara de lo que los españoles intentaban con implantar estas leyes. Art. 128. La tentativa para abolir o variar en España la religión católica, apostôlica, romana, será castigada con las penas de reclusión temporal y estrañamiento perpetuo, si el culpable se hallare constituido en autoridad pública y cometiere el delito abusando de ella. No concurriendo estas circunstancias, la pena será la de prisión mayor; y en caso de reincidencia, la de estrañamiento perpetuo. Art. 129. El que celebre actos públicos de un culto que no sea el de la religión católica, apostólica, romana, será castigado con la pena de estrañamiento temporal. 1) El que inculcare públicamente la inobservación de los preceptos religiosos. 2) El que con igual publicidad se mofare de alguno de los misterios o sacramentos de la Iglesia, o de otra manera excitare a su desprecio. 
República Dominicana. ${ }^{47}$ Además, era contrario a los tiempos anteriores en que existía libertad religiosa y se conocían congregaciones metodistas, bautistas y masónicas.

Los comerciantes, de igual forma, comenzaron a sentir el dolor de la querida anexión a España, pues fueron víctimas de altos impuestos por parte del gobierno español. Los españoles comenzaron a establecer impuestos a los barcos de otras naciones, con la idea de obligar a la República a comprar la mercancía de España o los productos que revendían de otras islas. Se creó entonces un monopolio de los productos españoles. ${ }^{48}$ Todo esto con-

${ }^{47}$ Sobre este particular véase Hoetink, Pueblo, 1971, pp. 25-50. Según Hoetink, "fue durante la presidencia haitiana de Boyer que llegó a Samaná el primer grupo de americanos de color". Esta idea de traer inmigrantes negros libres de Estados Unidos no era nueva en Haití. Ya en 1804, Desalines ofreció una recompensa de 40 dólares a los capitanes americanos por cada negro que trajeran de Estados Unidos. La necesidad de personas y mano de obra en la parte oriente de La Española durante este periodo se debe a su gran descenso en la población. Muchos se unieron en lazos matrimoniales para preservar su raza, al igual que su idioma. En cuanto a la religión, los inmigrantes lograron establecer varias iglesias metodistas en los alrededores, con el fin de preservar su cultura. Otros eran bautistas, contrario a los habitantes de la isla que eran en su mayoría católicos, como parte de la influencia española. Los colored people o negros estadunidenses, paulatinamente fueron integrándose a la comunidad, llegando a ocupar, muchos de ellos, puestos importantes en el gobierno dentro del distrito. Por ejemplo, en Samaná, en 1867, el colector del puerto y el gobernador del distrito eran ambos descendientes de los colored people.

${ }^{48}$ Los impuestos que establecieron los españoles para los buques extranjeros fueron desconsiderados. Las regulaciones establecían que los buques españoles pagarían 62.5 centavos por tonelada, mientras que los tribuyó a que paulatinamente se fuera forjando odio y resentimiento en contra de los españoles. Además, el comercio local y extranjero comenzó a sufrir las consecuencias. Durante el periodo del 1 de enero de 1861 al 30 de septiembre de 1861 , sólo ocho buques estadunidenses llegaron a los puertos dominicanos, en su mayoría antes del mes marzo. Durante diciembre del mismo año no arribaron buques estadunidenses, según informe del agente Elliot. En julio de 1861, William Cazneau le escribe a Seward diciéndole:

Como había anticipado y había tenido el honor de expresar en la correspondencia núm. 25 del pasado 25 de junio, el gobierno español está tomando medidas para lograr el perfecto control del pasaje de la Mona. ${ }^{49}$

Paulatinamente se fue revelando el intento español de dificultar el comercio para todos los demás extranjeros y el gran descontento que sentían los estadunidenses ante la situación de la isla.

Una medida que se realizó para evitar, hasta cierto punto, los altos impuestos que establecían los españoles, era cambiar

buques estadunidenses o extranjeros pagaban un dólar por tonelada. Esto haría que los productos de barcos estadunidenses o extranjeros se vendieran mucho más caros que los españoles. Todos los productos manufacturados en el extranjero pagaban una tarifa de $30 \%$, mientras que los mismos productos, pero españoles, sólo pagaban $6 \%$. De esa manera, se afectaba no sólo a los comerciantes extranjeros, sino a toda la industria, que pasaba por una de sus peores etapas. De igual forma, el dinero que circulaba era el que se le pagaba a los soldados para cubrir sus necesidades básicas, el cual sin duda era poco, ya que sólo había de 300 a 400 soldados para este entonces.

${ }^{19}$ William $\mathrm{L}$. Cazneau a William Seward, 2 de julio de 1861, CIH-UPR-RP-DCSD. 


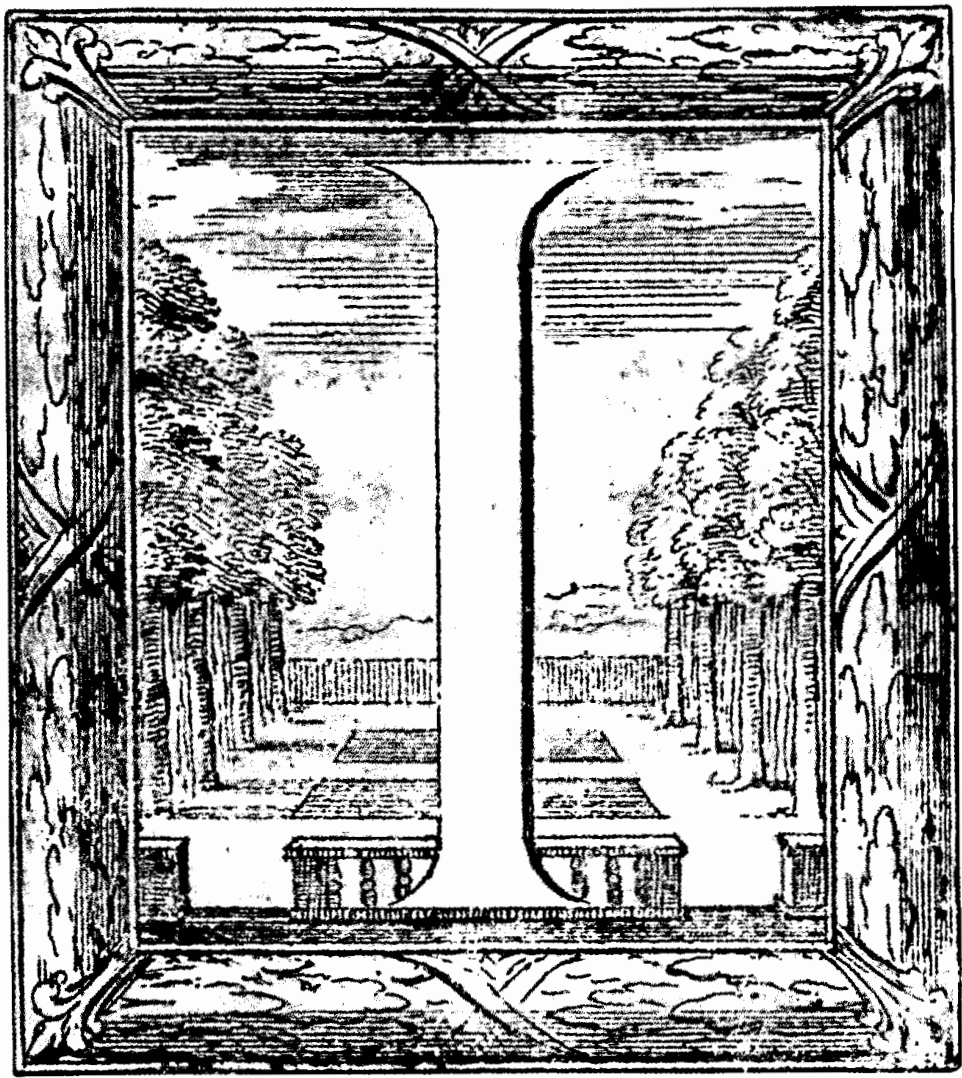


la nacionalidad de la bandera que tenía el buque:

La mayoría de los buques que han llegado aquí de Estados Unidos durante este año se han visto obligados a cambiar sus banderas de americana a inglesa, para así evitar impuestos excesivos y el ataque de piratas. ${ }^{50}$

Esta técnica se hizo muy famosa para esta época en la isla. Dinamarca controlaba la isla de St. Thomas, pieza clave para realizar esta maniobra. A la vez que Estados Unidos ejecutaba esta violación, los españoles, por su parte, llevaban a cabo otras que afectaban a los comerciantes estadunidenses. Según el agente comercial, desde que los españoles habían tomado posesión de República Dominicana se había despertado el comercio con Puerto Rico. Lo curioso no era el comercio que existiera con Puerto Rico, sino que los buques que llegaban desde este país traían productos estadunidenses y se vendían al mismo precio que si éstos se mercadearan directamente con Estados Unidos. El contrabando era fácil de realizar para estos buques españoles, pues no existía un control total, y mucho menos una inspección rigurosa. Otra realidad era que los inspectores encargados de esto regularmente eran personas $\sin$ mucho conocimiento de la materia. Muchos de ellos no sabían diferenciar la seda del propio algodón. Sus salarios eran muy bajos, por lo que se prestaban para cualquier cosa, con tal que se les diese algo de dinero o se le recompensara con mercancía.

Cabe señalar que durante los años de la anexión a España, la presencia de Estados Unidos se siguió haciendo sentir. Ya

so William Jaeger a William Seward, doc. 35, 2 de octubre de 1863, CIH-UPR-RP-DCSD. en 1860, algunos estadunidenses habían sentido la atracción del trópico. Incluso se podría decir que arriesgaron menos y ganaron mucho más que los españoles. Aunque no poseían tanto poder como éstos, no se habían enfrentado a una guerra abierta contra los dominicanos ni perdido tantos soldados y dinero. En 1862, quizás el mejor momento de la anexión a España, William Cazneau ${ }^{\text {s1 }}$ se dedicó a organizar la American West India Company, con un capital de 1000000 de dólares. ${ }^{52}$ W. Smith publicó un folleto titulado "The Gold Fields of Santo Domingo", que no era otra cosa sino propaganda para todos aquellos inversionistas que desearan llegar en busca de oro. Estaba dirigido a los empresarios que de alguna forma u otra no deseaban pasar por la pesadilla de la guerra civil por la que atravesaba Estados Unidos en ese momento:

Si los estadunidenses se habían expuesto a los peligros del Oeste desértico y a los salvajes y a las tormentas y a las fiebres de los viajes oceánicos en su búsqueda del oro de la lejana California, ¿por qué no precipitarse de inmediato sobre Santo Domingo donde la isla entera "es una inmensa mina de oro de un extremo al otro"? Además, una cantidad abundante de oro era sólo una de las miles de ventajas que la isla ofrecía. Existían muchos valles de "sabanas fabulosamente ricas", mientras que las tierras altas del interior eran ideales para fines de pasto. ${ }^{53}$

En 1863, Joseph Fabens, uno de los primeros empresarios estadunidenses en interesarse por la república, hizo otra

51 Para ver más sobre Cazneau véase, García y Lee, "Consular", 1998.

52 Tansill, Estados Unidos, 1977, p. 255.

${ }^{53}$ Ibid, p. 258. 
propaganda con intención de familiarizar a sus compatriotas con las muchas oportunidades que les ofrecía la isla. Publicó un libro titulado In the Tropics. Para los estadunidenses que estaban cansados de los largos inviernos norteños y que soñaban con un clima tropical donde resaltaran las bondades de la naturaleza, las descripciones de Fabens eran sin duda atrayentes. Fue mucha más la propaganda que estos señores hicieron para atraer personas. En 1863, Fabens leyó ante la Sociedad Geográfica y Estadística Norteamericana un pintoresco ensayo sobre Resources of Santo Domingo. ${ }^{54}$

Las consecuencias del descontento que comenzó a desatarse por los múltiples abusos fue el estallido "popular" en contra del gobierno español. Las primeras luchas comenzaron el 3 de febrero de 1863 en Neiba; luego surgió otra en Santiago el 24 del mismo mes, y otras siguieron gradualmente. La guerra por la "restauración", ${ }^{55}$ como mejor se le conoce, fue una guerra de guerrillas de pequeños grupos de personas, en su mayoría comerciantes de diversas áreas del país.

El 6 de abril de 1863, el gobierno español capturó un grupo de revolucionarios dominicanos que habían armado una revuelta en su contra. A cinco de ellos se les condenó a cadena perpetua; luego se les cambió la sentencia a trabajar como galeotes en la isla de Cuba por un periodo de 20 años. A otros 20 revolucionarios se les condenó por diez años, y a otros, con penas menores, a trabajar en la reconstrucción del país. Según los diversos cónsules en la isla, estas personas habían sido enjuiciadas injustamente, en violación de sus

${ }^{54}$ Ibid., p. 262.

55 Véase Domínguez, Anexión, 1979. derechos como ciudadanos. La inconformidad fue incrementándose hasta que los mismos españoles en la isla la empezaron a compartir. Muchas personas, entonces, comenzaron a pensar en una intervención de Estados Unidos como medio de establecer la paz:

La gente está muy insatisfecha con las nuevas leyes españolas, dado que ellos [los españoles] sólo han traído miseria y descontento. La comunidad entera rechaza la exacción de tributos, los impuestos exorbitantes y las leyes arbitrarias que tratan de forzar sobre una gente que una vez fue libre e independiente. La oración diaria del dominicano es por la pronta paz, para así apelar al poder magnífico de la república noble de Estados Unidos. ${ }^{56}$

La situación económica propiciaba que muchos comerciantes españoles, que habían visto la anexión con ilusión e interés personal y económico, decidieran marcharse a otras colonias españolas más seguras:

[...] muchos de los españoles inteligentes que esperaron encontrar aquí una California se han ido, y muchos otros se preparan para hacer lo mismo. Ellos están convencidos de que España nunca hará nada bueno aquí. La gente de la isla está muy opuesta al régimen español. España nunca será capaz de mantenerlos en calma y gobernar en paz. ${ }^{57}$

La mayoría de las revoluciones provenía de grupos de líderes aislados de diversas provincias de la isla, los cuales frecuentemente no tenían mucha comunicación entre sí y casi siempre actuaban indepen-

\footnotetext{
${ }^{56}$ William Jaeger a William Seward, doc. 22, 2 de julio de 1863, CIH-UPR-RP-DCSD.

${ }^{57}$ Ibid.
} 
dientemente. Sin embargo, los españoles pensaban que mucha ayuda en armas y municiones llegaba de los estadunidenses que apoyaban estas revoluciones:

Los españoles aquí les tienen un gran terror a los "yankees y el sueño poderoso que está sobre ellos". Ante cada revolución y disturbio que ocurre en esta isla, el grito inmediatamente de los españoles es "Oh, los yankees han aterrizado con hombres y armas". ${ }^{58}$

Las revoluciones fueron encabezadas principalmente por dominicanos -comerciantes, intelectuales y jefes de provincias- vistos por los demás ciudadanos como líderes. Las únicas armas que poseían eran sus espadas y utensilios para la siembra y cortar los pastos, que utilizaban para hacerse camino y llegar a otras provincias.

La situación de República Dominicana se volvió tan deprimente y angustiosa que todas las personas que creían en el progreso y la modernización y, sobre todo, los que tenían los medios para salir del país, lo hacían sin pensarlo:

La enferma temporada ahora comienza y los soldados españoles, los oficiales, extranjeros, y los nativos de las islas, se mueren en cantidades, debido al vómito negro del último lote de emigrantes (catorce en total) arrojados aquí por la American West India Company. En mayo nueve murieron, dos fueron a casa, el resto de los que vinieron han contraído la fiebre y no se espera que sobrevivan. ${ }^{59}$

${ }^{58}$ William Jaeger a William Seward, doc. 25, 31 de agosto de 1863, CIH-UPR-RP-DCSD.

59 William Jaeger a William Seward, doc. 22, 2 de julio de 863, CHH-UPR-RP-DCSD.
Esta situación incluía a los comerciantes estadunidenses que habían iniciado sus proyectos en la isla. Fabens y Cazneau empezaron a confrontar muchos problemas con la política española. Cuando la revolución comenzó, los españoles se tornaron muy agresivos como método de defensa para establecer respeto. Esto afectó mucho la empresa que Cazneau había organizado:

Cerca de doce o quince americanos llegaron algunas semanas atrás para asentarse aquí. Vinieron bajo los auspicios y persuasión de J. W. Fabens y W. L. Cazneau. Ahora todos piensan en regresar a Estados Unidos. ${ }^{(0)}$

El 28 de septiembre, el agente comercial Jaeger informó que los distritos del oeste -Bani, San Juan, Neyba, Azua y Maniel-habían declarado la guerra a los españoles. Muchos aún no se habían unido completamente a la revolución; sin embargo, esta vez se bajó la bandera de España y fue sustituida por la de República Dominicana. El gobernador se atemorizó tanto, conociendo el estilo de batalla que llevaban, que en la madrugada capturó a 36 de los hombres más respetables e influyentes de la región, y los envió en un pequeño buque español a una prisión en Puerto Rico. Entre los apresados se encontraba Joaquín Delmonte, influyente comerciante que había residido por varios años en Estados Unidos y el cual ya había obtenido sus primeros papeles de naturalización estadunidense. Según lo describe el agente comercial, Delmonte era un típico estadunidense: "He conocido al señor

${ }^{60}$ William Jaeger a William Seward, doc. 16, 6 de abril de 1863, CIH-UPR-RP-DCSD. 
Delmonte por los pasados cuatro años y estadunidense más leal de corazón no se puede encontrar." ${ }^{\prime \prime 1}$ Éste se encontraba en la isla en viaje de negocios, para luego regresar a Estados Unidos donde tenía su residencia. El gobierno español deportó a tres sacerdotes dominicanos para asegurar que todas las personas de influencia y los intelectuales estuvieran fuera del país.

Para Jaeger, los acontecimientos que se desataban en República Dominicana eran la oportunidad para que Estados Unidos actuara rápidamente. Por un lado, a cambio de la ayuda que Estados Unidos le brindara a los revolucionarios, podrían luego exigir un buen tratado en el comercio. Por otra parte, el cónsul Jaeger opinaba que si el presidente Lincoln y el Congreso buscaban un lugar para reubicar la raza de color para protegerla, el país era perfecto para estos menesteres, comparándola con su vecina Haití, cuya población era en su mayoría negra y no había habido problemas raciales mayores.

Además, en 1863, el agente comercial hizo comentarios sobre el cultivo de algodón en el país: este producto se había visto afectado en Estados Unidos por la guerra civil. El agente comercial señala que sería interesante hacer el experimento en República Dominicana, dado que ya los españoles estaban estableciendo el cultivo del algodón. Ésta fue una de las únicas aportaciones de la presencia y del control españoles, ya que este producto no se generaba en el país, y de 1863 a 1865 se obtuvieron de 2000 a 3000 quintales.

La situación de República Dominicana empeoró, ya que los propios españoles no estaban pagando a sus soldados ni a sus

${ }^{61}$ William Jaeger a William Seward, doc. 31, 28 de septiembre de 1863, CIH-UPR-RP-DCSD. empleados, lo que causó inconformidad entre los mismos españoles y, paulatinamente, contribuyó al fracaso de la anexión.

Casi un año antes del fin del control de España sobre República Dominicana, los efectos se estaban sintiendo en la economía del país. Los intereses de las grandes potencias se veían sumamente afectados, en especial, los de los capitalistas estadunidenses. Muchos de los productos de exportación de República Dominicana escaseaban debido a la guerra de restauración de independencia. Desde febrero, cuando se inició la guerra, la cantidad de barcos que salían del país descendió, causando la bancarrota de muchos capitalistas extranjeros. Por ejemplo, el agente comercial informó que hasta el 30 de septiembre de 1863 sólo dos buques estadunidenses habían llegado a Puerto Plata.

Luego de estas primeras revoluciones, el gobernador español don Felipe Ribero y Lemoyne declaró al país en estado de sitio. Curiosamente, esta orden especifica en el artículo 2 que "se crea una comisión militar ejecutiva y permanente en la provincia de Santiago de los Caballeros con el objeto de instruir, sustanciar y fallar las causas de conspiración, infidencia y rebelión contra el Estado". ${ }^{62}$ En esta provincia habían comenzado las primeras revoluciones. Santiago era una de las provincias más importantes, una de las de mayor población y comercio: "Santiago es para Santo Domingo lo que Nueva York es para Estados Unidos." ${ }^{63}$

62 "Bando, orden y mando, del gobernador y capitán general de la parte española de la isla de Santo Domingo y general en jefe del ejército de la misma", 24 de agosto de 1863, CIH-UPR-RP-DCSID.

${ }^{63}$ William Jaeger a William Seward, doc. 29, 21 de septiembre de 1863, CIH-UPR-RP-DCSD. 
El 19 de octubre, el cónsul estadunidense en Santo Domingo informó que los revolucionarios habían tomado la provincia de Azua. El gobierno español envió un centenar de soldados a esta provincia y declaró a todos los ciudadanos que permanecieran en ella, como enemigos del gobierno español:

... se esperaban 30000 tropas de España, éstas debían marchar por el país para asolar y destruir todo. Los que se opusieran y permanecieran en Azua serían considerados y tratados como rebeldes y enemigos del gobierno español. ${ }^{64}$

La provincia de Azua era de las más ricas e importantes de República Dominicana y era considerada una de las áreas de más comercio, de hecho la mayor en la región oeste. Sus plantaciones de azúcar estaban entre las de mayores ganancias, ya que poseía su propio puerto de entrada. Sus recursos naturales eran bastante abundantes; además, contaba con los mejores caminos y carreteras. El gobierno español, actuando de mala voluntad y sabiendo que no tenía los medios para capturar la provincia o mantenerla en manos españolas, prefirió destruirla por completo; esto afectó a todos los comerciantes, que tuvieron que abandonar la provincia de Azua y quedar en la ruina. "Todas las casas del lugar han sido abandonadas, con todas sus cosas, incluyendo la ropa", 65 señaló el estadunidense Jaeger.

Tras la situación de Azua, el agente comercial estadunidense hace un plantea-

\footnotetext{
${ }^{64}$ William Jaeger a William Seward, doc. 38, 19 de septiembre de 1863, CIH-UPR-RP-DCSD.

${ }^{65}$ Ibid., 19 de octubre de 1863 , CIH-UPR-RPDCSD.
}

miento al secretario de Estado de Estados Unidos:

Los españoles tendrán que pagar caro por este ultraje. Ellos ya saben que aquí no los quieren y están obligados a salir lo antes posible. No están autorizados a sacar a las personas de sus casas, destruyéndolas y dejando al país en la ruina. ${ }^{66}$

Los cónsules y las personas que tenían puestos importantes en los asuntos exteriores sabían que a los españoles les quedaba muy poco tiempo en el país. El cónsul estadunidense expresó: "en mi opinión, ni 15000 españoles pueden conquistar nuevamente esta isla". ${ }^{67}$

Según relata Jaeger, varias veces se trató de apelar a la justicia en contra de los abusos que se cometían en contra de los capitalistas y productos estadunidenses. Se llevaron varios casos hasta los más altos niveles de autoridad del gobierno español, sin alcanzar mucho fruto. La respuesta de estos oficiales fue "que ésas eran las leyes españolas y que ellos no podían interferir o cambiar las leyes establecidas". ${ }^{68}$ Era claro que existía un conflicto de intereses personales e institucionales: por un lado, el interés del empleado que se beneficiaba de violar las leyes y, por otro, los intereses institucionales de la corona española que, a sabiendas, violaban los derechos en beneficio propio.

Esto no evitó que muchos estadunidenses lucharan por obtener concesiones para explotar las minas y otros privilegios; el gobierno no se negó a darles varias

${ }^{66} \mathrm{Ibid}$.

${ }^{67} \mathrm{Ibid}$.

${ }^{68}$ William Jaeger a William Seward, doc. 35, 2 de octubre de 1863, CIH-UPR-RP-DCSD. 
de éstas. Una de las concesiones más importantes fue adjudicada en febrero de 1863 a David Hatch, y le permitía trabajar las minas de sal de Neyba, ubicadas en la costa sur del país. La compañía tenía control absoluto de la sal de este distrito por un término de 99 años. De igual forma, tenía derecho a la construcción de un ferrocarril desde las minas hasta Barahona, el cual recorrería una distancia de alrededor de 30 millas. La inversión en el ferrocarril y toda la maquinaria sobrepasaba 1000000 de dólares. Una de las cláusulas importantes que poseía esta concesión era que una vez expirada, todo lo construido pasaría a manos del gobierno dominicano. Esto no era un elemento muy bien visto, ya que para los españoles y sus leyes $\tan$ fuertemente diseñadas en contra de las potencias extranjeras, no tesultaba viable construir e invertir tanto para otros.

Los habitantes de la república sentían que los abusos de los españoles estaban llegando al nivel más alto jamás visto. Un afectado fue, por ejemplo, John George Pfister, nativo de Basel, república de Suiza, quien había establecido negocios en la provincia de Santiago por varios años y fue víctima injusta de la guerra y de las destrucciones españolas. En la devastación del 6 de septiembre de 1863, Pfister perdió su casa y varias propiedades, que en total representaron 10060 dólares. Un incendio terminó prácticamente con la provincia, lo cual ilustra la fragilidad de los intereses de los extranjeros del país. El señor Pfister apeló al cónsul estadunidense, como correspondía, ya que en la isla no existía cónsul de Suiza. ${ }^{69}$ Éste es

${ }^{69}$ John G. Pfister to the Consul of United State in Dominican Republic, 31 de octubre de 1863, CIHUPR-RP-DCSD. uno de muchos casos en que la crisis afectó las propiedades de los extranjeros en la República.

Otro caso similar fue el del mismo William Cazneau, quien perdió completamente su casa y la estancia La Esmeralda, ubicadas en la provincia de San Carlos y compradas, según los registros de propiedad, en 1855 . Hasta el día en que los soldados españoles sacaron a toda su familia de la casa, Cazneau había vivido con mucha tranquilidad, aunque todos supieran que era estadunidense. Durante las revueltas de la restauración, los españoles lo sacaron de su casa señalando que ésa era zona militar y que él la había comprado bajo el gobierno español-dominicano. Las palabras de Cazneau son muy directas en la carta que escribe al secretario de Estado: "Estas personas están tomando ventaja de los problemas que tenemos actualmente en Estados Unidos; han establecido una monarquía en una tierra que era completamente libre." 70 Al igual que para Cazneau, la única esperanza de los dominicanos residía en Estados Unidos: "Los dominicanos no desean más monarquías, ahora ven que su única esperanza para obtener la paz es Estados Unidos" ${ }^{71}$ Según varias personas, entre ellas los cónsules de Francia e Inglaterra, la propiedad de Cazneau había sido destruida maliciosamente y sin ninguna razón ni necesidad. La estancia La Esmeralda constaba de varios acres de tierra, muchos a orillas del río Ozama y contenía un sinnúmero de árboles frutales y edificios, todos los cuales fueron destruidos. Cazneau alegó que había invertido mucho tiempo, labor

${ }^{70}$ William L. Cazneau to the Department of States, 25 de diciembre de 1863, CIH-UPR-RP-DCSD.

${ }^{71}$ Ibid. 
y, sobre todo, dinero en su desarrollo, y por su destrucción injustificable pedía la suma de 10000 dólares, que no serían otra cosa que una indemnización por ser víctima del conflicto.

Para enero de 1864, ya la derrota de los españoles era inminente: "los españoles siguen aguantando, pero sin mostrar mucho avance ni progreso en contra de la revolución". ${ }^{72}$ La situación de España era deprimente: las continuas batallas en República Dominicana los obligaban a seguir enviando soldados de Es̄paña, Cuba y Puerto Rico, los cuales morían con facilidad, no sólo por las guerrillas, sino por las enfermedades. Se informó que de un grupo conjunto de Cuba y Puerto Rico llegaron unos 24000 soldados; de ésos, 5000 fueron asesinados por los guerrilleros, y otros 7000 padecían gravemente de la fiebre amarilla y otras enfermedades. A estos últimos se les envió a Cuba y murieron más de la mitad en el viaje. ${ }^{73} \mathrm{El}$ cónsul de Estados Unidos dictaminó: "España, ni trayendo una gran cantidad de tropas aquí, es capaz de mantener este territorio, sólo la tierra de donde vienen." 74

Al finalizar la guerra y conseguida la libertad deseada, el país quedó devastado, con inmensas pérdidas en el comercio y el abandono total de la agricultura, ya que

${ }^{72}$ William Jaeger a William Seward, doc. 8, 28 de enero de 1864, CIH-UPR-RP-DCSD.

${ }^{73} \mathrm{En}$ el país quedaban alrededor de 12000 soldados, de los cuales 3000 o 4000 estaban en el hospital por heridas y problemas leves. Este ejemplo es uno de los muchos y muy significativos que ayudan a ver cómo un simple "capricho" de parte de España derrumbaba todo un imperio, más aun cuando la guerra ya estaba perdida.

${ }^{74}$ William Jaeger a William Seward, doc. 8, 28 de enero de 1864, CIH-UPR-RP-DCSD. todos tuvieron que tomar las armas en contra de los españoles. La destrucción del consulado estadunidense en la provincia de Puerto Plata ilustra estas circunstancias: un fuego desatado el 30 de junio de 1863 destruyó prácticamente esta provincia. Las llamas, según la descripción del agente comercial estadunidense Lighgow, duraron alrededor de 30 horas, y destruyeron la casa alcaldía y todas las áreas comerciales de la provincia. Las pérdidas ascendieron a 1000000 de dólares.

En el ámbito político, las guerrillas provocaron que el país quedara prácticamente dividido en muchas regiones en donde gobernaba un caudillo. La mayoría de estos líderes estaban ligados al comercio y tenían poca o ninguna instrucción académica. Dentro de este grupo de personas comienza la lucha por el poder político.

Luego del fracaso anexionista español, Seward, el secretario de Estado, no desea intervenir ni ofrecer nada a los dominicanos, ya que sabe bien que en ellos sólo quedan resentimiento y odio a la anexión. De igual forma, la fragmentación de la dirección del país por diversos líderes o caciques haría muy difícil un consenso para una decisión. Una vez que todos conocieron la derrota de España, los agentes comerciales y cónsules de las potencias extranjeras comentaron sobre el futuro de República Dominicana. El cónsul estadunidense William A. Read informó en marzo de 1865 que el país necesitaba personas con habilidades y conocimientos en agricultura y comercio. De igual forma, propuso la idea de preparar compañías estadunidenses para estos fines, ya que otras potencias intentaban realizar lo mismo, una vez que los españoles abandonaran República Dominicana. Una nueva etapa 
de la presencia estadunidense en República Dominicana parecía comenzar.

\section{CONCLUSIÓN}

El periodo de 1844 a 1865 en República Dominicana se caracterizó por la competencia y la rivalidad entre las potencias internacionales, todas en busca de poder económico y político. Para España, la manera de demostrar su poderío fue anexar al país, lo cual funcionó por un tiempo y finalmente fracasó. Esto, sin embargo, servirá de modelo a otros políticos, que repetirán lo mismo que Santana, pero con otras potencias.

Durante todo momento de este periodo, Estados Unidos mantuvo su presencia en República Dominicana mediante los agentes comerciales o cónsules. Éstos quisieron actuar en varios momentos, pero las limitaciones de su puesto y las debidas a la guerra civil lo impidieron. Ahora nuevos y distintos intentos de anexión resucitarán en República Dominicana. El ejemplo más conocido será el de Buenaventura Báez con Estados Unidos. Durante ese periodo figurará prominentemente Seward, con más determinación y sin los problemas internos de la guerra civil de Estados Unidos.

\section{FUENTES PRIMARIAS DOCUMENTALES}

CIH-UPR-RP-DCSD Centro de Investigaciones Históricas, Universidad de Puerto Rico, Recinto Río Piedras. Despatches from United Status Consuls in Dominican Republic, 1837-1906. serie T-56, carretes 1-18.

\section{HEMEROGRAFÍA}

Gaceta Oficial de Santo Domingo, 1863.

\section{FUENTES SECUNDARIAS}

-Archambault, Pedro, Historia de la Restauración, Ediciones Taller, Santo Domingo, 1981.

-Báez Everstsz, Franc, La formación del sistema agroexportador en el Caribe, Repuiblica DominicanaCuba, 1815-1898, Editorial de la Universidad UASD, Santo Domingo, 1986.

-Bell, Ian, The Dominican Reprublic, Wetsview Press, Colorado, 1981.

-Betances, Emilio, State and Society in the Dominican Republic, Westview Press, Colorado, 1995.

-Betances de Pujadas, Estrella, Origen y proyecciones del protectoralismo dominicano, Alfa y Omega, Santo Domingo, 1979.

-Boin, Jacqueline y José Serulle Ramia, $E l$ proceso de desarrollo del capitalismo en la República Dominicana (1844-1930), Gramil, Santo Domingo, 1982.

-Bonó y Mejía, Pedro F., Papeles de Pedro F. Bonó: para la bistoria de las ideas politicas en Santo Domingo, Editora del Caribe, Santo Domingo, 1964.

-Bosch, Juan, La guerra de la Restauración, Corripio, Santo Domigo, 1982.

-Cassá, Roberto, Historia social y económica de la República Dominicana, Corripio, Santo Domigo, 1982.

-Cross Beras, Julio A., Sociedad y desarrollo en República Dominicana 1844-1899, CENAPEC, Santo Domingo, 1985.

-De la Rosa, Antonio, Las finanzas de Santo Domingo y el control americano, Editorial Nacional, Santo Domingo, 1915.

-Denis, Watson, "Anexionismo dominicano y política exterior de España, 1861-1865, fracaso de una estrategia de reconquista colonial en el Caribe", Programa Graduado de HistoriaFacultad de Humanidades-Universidad de 
Puerto Rico, Río Piedras, abril de 2000 , documento inédito.

-Domínguez, Jaime de Jesús, Economía y politica en la República Dominicana, 1844-1861, Universidad Autónoma de Santo Domingo, Santo Domingo, 1977.

- La anexión de la República Dominicana a España, Universidad Autónoma de Santo Domingo, Santo Domingo, 1979.

- Notas económicas y políticas sobre el periodo julio 1865- julio 1886. Tomos 1 y II, Universidad Autónoma de Santo Domingo, Santo Domingo, 1983.

- La dictadura de Ulises Heureaux 1886-1899, Universidad Autónoma de Santo Domingo, Santo Domingo, 1986.

-El libro azul, Universidad Autónoma de Santo Domingo, Santo Domingo, 1976.

-Franco Pichardo, Franklin J., República Dominicana, clases, crisis y comandos, $\mathrm{La}$ Casa de las Américas, Habana, 1966.

-García, Humberto y José Lee Borges, "U. S. Consular Activism in the Caribbean, 17831903, with Special Reference to St. Kitts-Nevis 'Sugar Depression, Labor Turmoil and its Proposed Acquisition by the United States", Revista Mexicana del Caribe, núm. 5, año 3, 1998.

-Garrido, Víctor, Política de Francia en Santo Domingo, 1844-1846, Editora del Caribe Santo Domingo, 1962.

-Grullón, Ramón, República Dominicana: una dictadura al servicio del imperialismo, Tribuna de México, México, 1954.

-Henríquez Ureña, Max, Los yanquis en Santo Domingo: la verdad de los bechos comprobada por datos y documentos of iciales, Imprenta M. Aguilar, Madrid, 1929.

-Herrera, César, Las finanzas de la República Dominicana, Impresora Dominicana, Ciudad Trujillo, 1955, vol. I.

-Hoetink, Harry, Santo Domingo y el Caribe: ensayos sobre bistoria y sociedad, Fundación Cultural Dominicana, Santo Domingo, 1994.
, El pueblo dominicano, 1850-1900, Universidad Católica Madre y Maestra, Santiago, 1972.

-Knight, Melvin Moses, Los americanos en Santo Domingo: episadios de imperialismo americano, Editora de Santo Domingo, Santo Domingo, 1980.

-Landolfi, Ciriaco, Introducción al estudio de la bistoria de la cultura dominicana, Universidad Autónoma de Santo Domingo, Santo Domingo, 1977.

_... Evolución cultural dominicana 18441899, Universidad Autónoma de Santo Domingo, Santo Domingo, 1981.

-Latorres, Eduardo, "The Dominican Republic: a Case Study of a Caudillistic Political System and the Challenge of a Populist Movement", tesis doctoral, Columbia University, Nueva York, 1972.

-Jiménez Grullón, Juan I., Jobn Bartlow Martin un procónsul del imperio yanqui, (respuesta a su libro El destino dominicano), Talleres Gráficos, Venezuela, 1977.

, Sociología política dominicana 18441966, Alfa y Omega, Santo Domingo, 1982.

-Maríñez, Pablo, El Caribe bajo las redes politicas norteamericanas, Universidad Autónoma de Santo Domingo, Santo Domingo, 1987.

-Marte, Roberto, Estadísticas y documentos bistóricos sobre Santo Domingo (1805-1890), Museo Nacional de Historia y Geografía, Santo Domingo, 1984.

-Martínez, Rufino, Diccionario biográfico-bistórico dominicano 1821-1930, Universidad Autónoma de Santo Domingo, Santo Domingo, 1971, Historia y Sociedad, 5).

-Moya Pons, Frank, La dominación haitiana 1822-1844, Universidad Católica Madre y Maestra, Santiago, 1978.

—, Manual de bistoria dominicana, Universidad Católica Madre y Maestra, Santiago, 1981.

- Historia colonial de Santo Domingo, Universidad Católica Madre y Maestra, Santiago, 1974. 
-Muñoz, María Elena, Historia de las relaciones internacionales de la República Dominicana, Universidad Autónoma de Santo Domingo, Santo Domingo, 1979.

-Padilla, José M., "Economía portuaria y desarrollo urbano en Puerto Plata: 1844-1930", tesis doctoral, Universidad de Puerto Rico-Programa Graduado de Historia, Río Piedras, 1998.

-Pérez, Carlos Federico, Historia diplomática de Santo Domingo, (1492-1861), Imprenta de la Escuela de Servicios Internacionales/Universidad Nacional Pedro Henríquez Ureña, Santo Domingo, 1973.

Price-Mars, Jean, La République d'Haiti et la République Dominicaine; les aspects divers d"un problème d'histoire, de géographie et d'ethnologie. Depuis les origènes du peuplement de l'ile antiléenne en 1492, jusqu'a l'évolution des deux États qui en partagent la souveraineté en 1953, s. e., Port-auPrince, 1953, 2 vols.

-Rodríguez Demorizi, Emilio, Hostos en Santo Domingo, Imprenta J. R. Vda. García Sucs., Ciudad Trujillo, 1939.

- La era de Francia en Santo Domingo, "contribución a su estudio", Editora del Caribe, Ciudad Trujillo, 1955.

- Documentos para la bistoria de la República Dominicana, Impresora Dominicana, Ciudad Trujillo, 1959, vols. I-III.

- Próceres de la restauración, noticias biográficas, Editora del Caribe, Santo Domingo, 1963.
- Santo Domingo y la gran Colombia, Bolívar y Núñez de Cáceres, Editora del Caribe, Santo Domingo, 1971.

-San Miguel, Pedro L., Los camperinos del Cibao, Universidad de Puerto Rico, Río Piedras, 1997.

-Schoenrich, Otto, Santo Domingo un país con futuro, Editora de Santo Domingo, Santo Domingo, 1977.

-Serulle Ramia, José, La inversión de capitales imperialistas en la Repuíblica Dominicana elementos de crítica a la teoría de la dependencia, Gramil, Santo Domingo, 1981.

-Stuart, Graham H., American Diplomatic and Consular Practice, D. Appleton-Century Company, New York, 1936.

-Tansill Callan, Charles, Los Estados Unidos y Santo Domingo 1798-1873, Editora de Santo Domingo, Santo Domingo, 1977.

-Vesser, Cyrus Richard, "Remapping the Caribbean; Private Investment and United State Intervention in the Dominican Republic, 18901908", tesis doctoral, Columbia University, Nueva York, 1997.

—_ A World Safe for Capitalism, Dollar Diplomacy and America's Rise to Global Power, Columbia University Press, Nueva York, 2002.

-Welles, Sumner, La viña de Nabotb: la Repriblica Dominicana, 1844-1924, Taller Santo Domingo, 4a. ed., Santo Domingo, 1981, 2 vols.

-Williams, Eric, From Columbus to Castro: the History of the Caribbean, Harper and Row, Nueva York, 1973. 